\title{
Sustainable Infrastructure and Conservation Ideas on Homestay Modification; Owners' Motivation and Tourists' Satisfaction in Amphawa, Thailand
}

\author{
N. Suebsuk and O. Nakagawa
}

\begin{abstract}
In 2001 the conservation and restoration campaign along the Amphawa Canal begans. Many development projects launched by the public and private sectors bring a large number of tourists. However this can have a negative impact on many traditional sites. According to the campaign, people in the community revive traditional water-based tourism by stimulating the use of traditional buildings along the canal and modifying them into commercial and tourist accommodation. This paper mainly focuses on how private individuals modify historical structures, the users' and tourists' (guests') points of view on modification of traditional houses to homestays in Amphawa. Motivational factors in user scales from the community (village) and identification and satisfaction from tourists' (guests) in accordance with sustainable tourism concepts are presented through the ideas of cultural conservation of traditional building design, cultural activities, traditional celebrations, and the local way of life along the Amphawa Canal.
\end{abstract}

Index Terms-Amphawa homestay, tourists' satisfaction, traditional building modification, users' approach, Water-based tourism.

\section{INTRODUCTION}

The study of tourism development in Thailand started with the first National Tourism Development Plan in 1976; over five decades ago, and shows that most local communities are unable to cope with the rapid growth of the tourism industry. Only a few of them can successfully develop into sustainable tourism destinations.

"After development of Thailand's First National Tourism Development Plan in1976, tourism has brought about the highest income in service sectors in over five decades. It has become the main industry to stimulate economic growth and played an important role in creating economic recovery of the country during the economic crisis in 1997" [1].

From Fig. 1 [1]-[4], since the late 1990s, globalization has had a crucial effect on the economic and social development of Thailand. After the economic crisis in 1997, the Thai government reviewed and adapted new concepts of tourism development into The National Economic and Social Development Plan. The idea of decentralization was applied. More focus is on local economic development. Local

Manuscript received December 9, 2013; revised February 26, 2014. This work was supported in part by the U.S. Department of Commerce under Grant BS123456.

The authors are with the School of Science and Technology, Department of Architecture and Design, Kyoto Institute of Technology, Kyoto, Japan (e-mail: naphasinees@gmail.com,nakagawa@kit.ac.jp). participation in natural resources management and cultural restoration are essential instruments in creating the sustainable development of communities. Progressive localism and ecotourism were added to The Eighth National Tourism Development Plan in 1997-2001 [5]. Follow the observations, interviews, and relevant research studies, all data culminated in a time line, providing a clearer overall picture. The time line of each thirty year period related to social and cultural changes in local communities in Thailand and can be divided into three stages; subsistence agriculture, commercial agriculture, and global tourism. Global tourism directly and indirectly affects the patterns of local community.

Amphawa is one of the most interesting cities in Thailand. It represents the cultural significance of the country through a lively water-based community originating since Ayutthaya Period (1893-2310 B.E.). In the past, Amphawa was the centre of a water-based market and agricultural community along the Mae Klong River. However, since 1974, local aspects of Amphawa have gradually changed due to the development of road transportation and decline of water-based activities. From 2001, a group of instructors from the Faculty of Architecture, Chulalongkorn University has started a conservation and restoration campaign in Amphawa. Many development projects have also been launched by the public and private sectors, these reviving traditional water-based tourism and bringing a large number of tourists to the city. Significant changes to this water-based community consist of an expansion in souvenir shops and food stalls, and the modification of traditional buildings to provide commercial and tourist accommodation. Interviews with local people who have transformed their houses into homestays from the beginning of the restoration plans in 2001 to the present (2013) create a better understanding of the users' and tourists' points of view on the sustainable infrastructures for modifying traditional dwelling houses into tourist accommodation or homestays along the Amphawa Canal.

Amphawa has accordingly been changed from a water-based interdependent community into a commercial town and tourist attraction. Although an increasing number of tourists have brought rapid changes to local communities in Amphawa over the past ten years, the cultural identity of the place still exists. The rapid growth of tourism has a prominent influence on the expansion of commercial resorts and home stays in Amphawa. In the past twelve years, 91.01\% of traditional dwelling houses along the canal have been transformed into commercial and tourist 
accommodation. The 2012 survey also shows that the commerce. (Table I) [6], [7]. number is likely to increase for the purpose of trade and

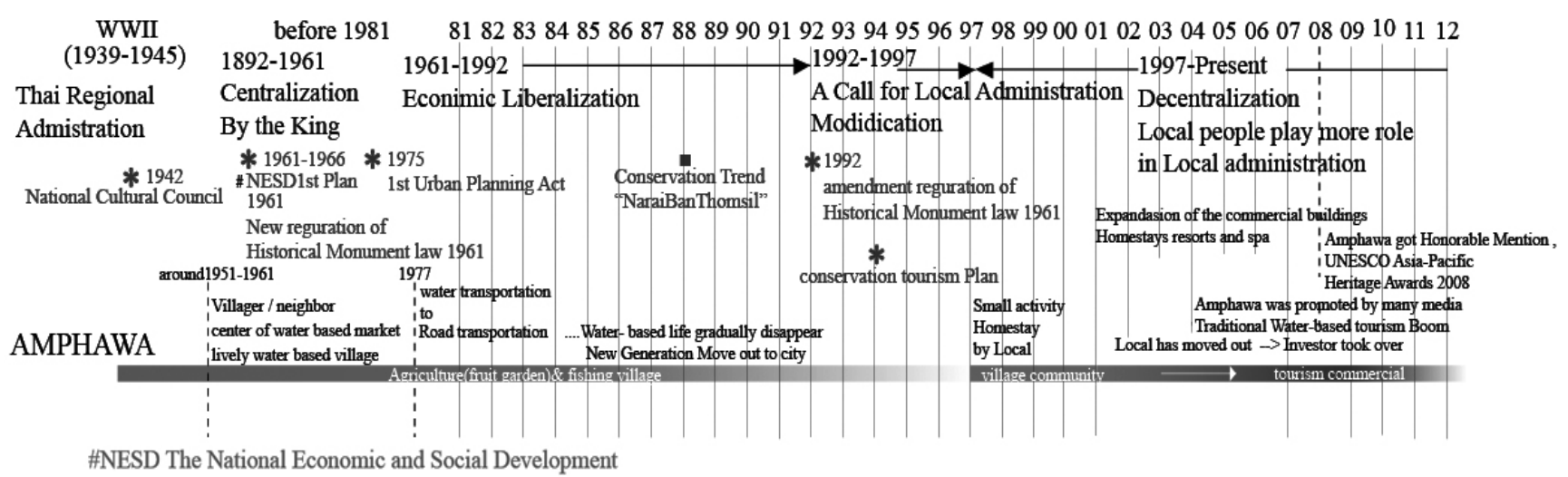

Fig. 1. A time line explaining social and cultural changes in Amphawa local communities, Thailand.

TABLE I: THE CHANGES IN LAND AND BUILDING USE IN AMPHAWA MUNICIPALITY: EFFECTS FROM RESTORATION AND DEVELOPMENT PLANS IN LOCAL COMMUNITY DURING 2001-2013.

\begin{tabular}{|l|r|r|r|r|r|r|}
\hline \multicolumn{1}{|c|}{ Conservation } & \multicolumn{3}{c|}{ Buildings along Amphawa Canal (Unit) } \\
\hline \multicolumn{1}{|c|}{ By Function } & \multicolumn{2}{|c|}{$2001 *$} & \multicolumn{2}{|c|}{2012} & \multicolumn{2}{c|}{ change } \\
\hline Dwelling House & 202 & $55.65 \%$ & 105 & $25.86 \%$ & -97 & $-48.02 \%$ \\
\hline Commercial & 5 & $1.38 \%$ & 85 & $20.94 \%$ & 80 & $1600.00 \%$ \\
\hline $\begin{array}{l}\text { Commercial \& Living } \\
\text { House } \\
\text { (Homestay\&Shophouse) }\end{array}$ & 89 & $24.52 \%$ & 170 & $41.87 \%$ & 81 & $91.01 \%$ \\
\hline $\begin{array}{l}\text { PublicBuilding(Market } \\
\text { Information Center } \\
\text { Museum) }\end{array}$ & 12 & $3.31 \%$ & 32 & $7.88 \%$ & 20 & $166.67 \%$ \\
\hline Empty House & 55 & $15.15 \%$ & 14 & $3.45 \%$ & -41 & $-74.55 \%$ \\
\hline Summary & 363 & $100 \%$ & 406 & $100.00 \%$ & 43 & $11.85 \%$ \\
\hline
\end{tabular}

This paper focuses on the sustainable infrastructure from the point of view of the homestay owners' and tourists' on the modification of historical buildings along the Amphawa Canal.

The study aims to encourage common understanding and respect for traditional cultures and the natural environment among the users and tourists.

The researcher hopes that the opinions of the tourists and homestay owners, together with recommendations and research results will prove useful to any interested agencies in the creation of appropriate regulations to protect the originality and identity of Amphawa. The study also aims to encourage further research to facilitate the progress of a place or region towards the goal of sustainable living.

\section{SCOPE OF THE STUDY}

The scope of the study focuses on the idea of urban heritage conservation and sustainable infrastructure development to provide an overall image of its rehabilitation. Having regard to the outcome of the previous paper. [7] The survey and study focuses along the Amphawa Canal at the location of the main sustainable tourism site (Fig. 2.)[8].

1) To explore building functions and owners' right of the eighteen historical buildings transformed into homestays along the Amphawa Canal (Fig. 3).

2) Analyze the idea of modifying historical buildings belonging to twelve homestay owners who also use the building as their permanent home.

3) To identify the relationship between cultural and traditional destinations and the satisfaction of tourists who visit cultural destinations with sustainable urban infrastructures for representing the understanding of Amphawa's identity through tourist accommodation or homestays.

The development and rehabilitation of Amphawa's buildings can be explained as follows (see Fig. 4).

The ideas of heritage conservation and sustainable tourism in Amphawa after the development of homestays along the Amphawa Canal are reviewed from perspectives of Associate Prof Wannasilpa Peerapun Ph.D., Chulalongkorn University, Associate Prof Siriwan Silapacharanan, Ph.D. and Lieutenant Patcharodom Ounsuwan. Associate Prof Wannasilpa Peerapun Ph.D. and Associate Prof Siriwan Silapacharanan, Ph.D. These are the individuals who initiated the conservation plans in Amphawa and promoted the place as a traditional water-based tourist destination until it was nominated for an honorable mention for the UNESCO Asia-Pacific Heritage Award in 2008 as shown on following chart in Fig. 5.

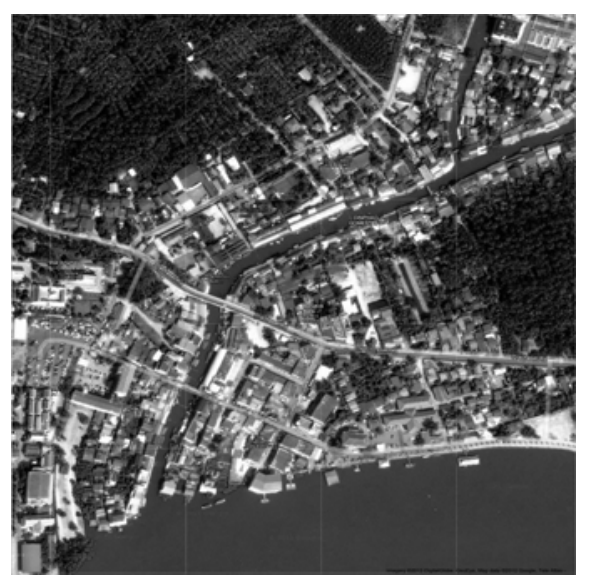

Fig. 2. Amphawa canal. 


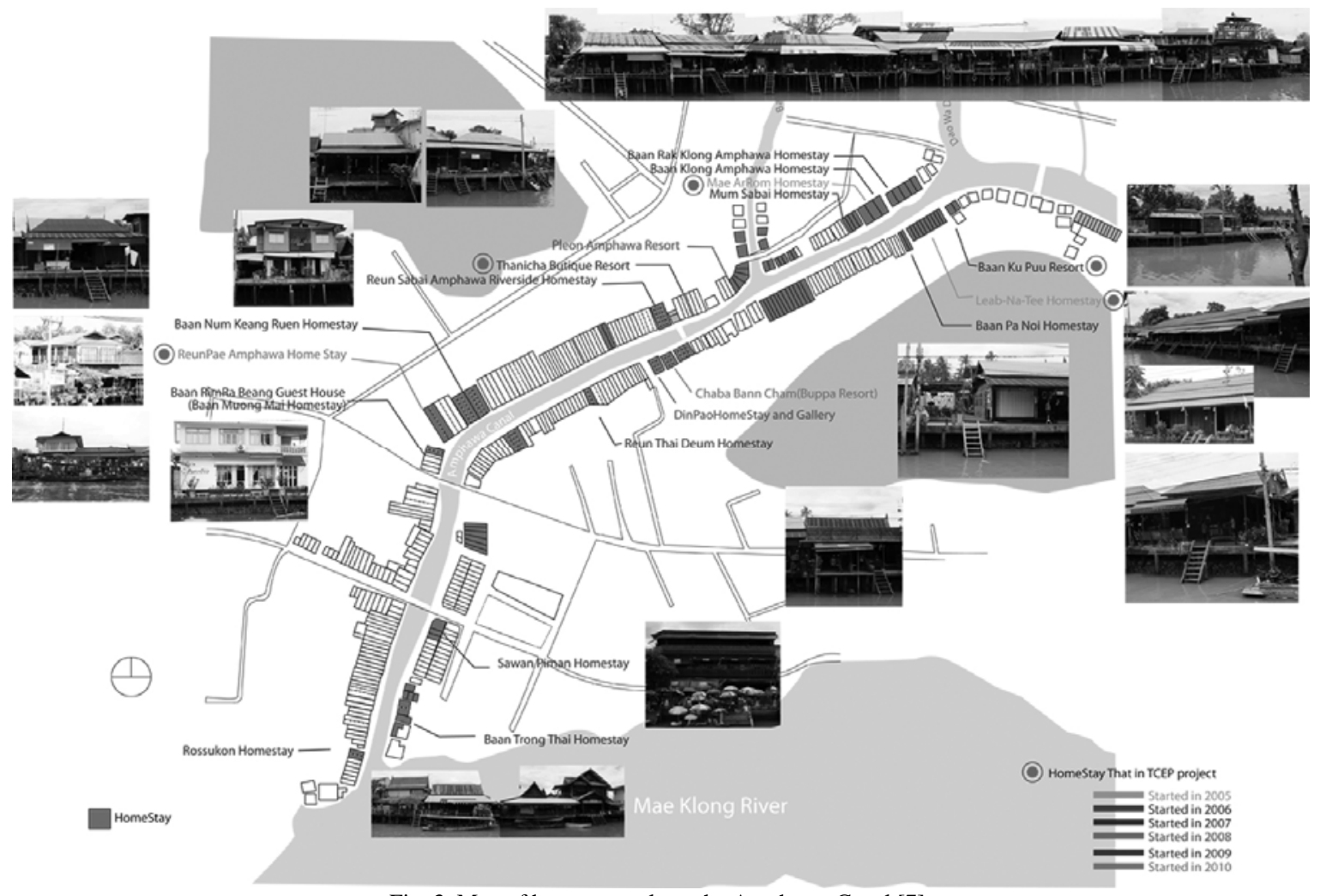

Fig. 3. Map of homestays along the Amphawa Canal [7].

$\begin{array}{ll} & \begin{array}{l}\text { Develop \& rehabilitation building } \\ \text { Renovated 1 TCEP Home stay } \\ \text { (Started in 2001) }\end{array} \\ 2004 & \begin{array}{l}\text { 2 TCEP Homestays were founded } \\ \text { (One of them 2005-2010 and re-started in 2012) }\end{array} \\ \mathbf{2 0 0 5} & \begin{array}{l}\text { 1 TCEP Homestay House was founded } \\ \text { 6 River based Homestays were founded }\end{array} \\ \mathbf{2 0 0 6} & \text { 2 River based Homestays were founded } \\ \mathbf{2 0 0 7} & \text { 1 River based Homestay was founded } \\ \mathbf{2 0 0 8} & \begin{array}{l}\text { 1River based Homestay was transferred } \\ \text { to another owner(2007) } \\ \text { 3 River based Homestays were founded }\end{array} \\ \mathbf{2 0 1 1} & \text { 1River based Homestay was founded } \\ \mathbf{2 0 1 3} & \text { 1River based Home stay is under construction }\end{array}$

Fig. 4. The Development of a Rehabilitation building for Homestay in Amphawa.

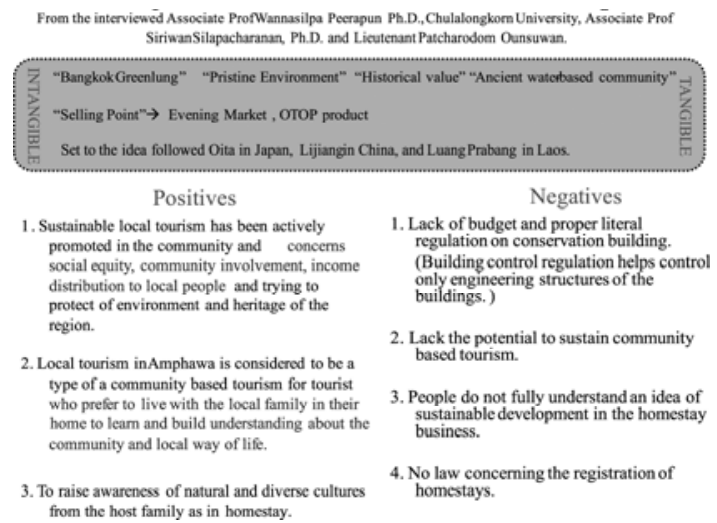

Fig. 5. The image of the rehabilitation idea (tangible/ intangible, positive impact/negative Impact) in Amphawa from the interviews on August 2012 and March 2013.

\section{THE IDEA OF THE MODIFICATION OF HisTORICAL}

BUILDINGS USED FOR A GROUP OF HOMESTAYS ALONG THE

$$
\text { AMPHAWA CANAL }
$$

From the survey, home stay houses along the Amphawa
Canal possess timeless architectural heritage with unique features and in material used, together with roof, door and window design, and ventilator style (Fig. 6).

From Data collection on site, the functions of the buildings have been changed from residential houses, buildings for rent; company, organization/ foundation offices, and abandoned houses to homestay businesses (see Fig. 7).

This is the response to the restoration project of the Amphawa Floating Market and investment opportunities and possible profits expected by most residents.

Building functions can be divided into three categories:

Home stay where the guest lives together with the owner of the building. The guest is treated like a friend or a member of the family. The host may provide some cultural activities for the participation of the guest during their stay.

Most homestays of this type keep the original structure of the buildings' without making any changes and the buildings are still in use for the daily lives of the family.

Homestays that possess home-like characteristics. Traditional features of the house have been well preserved and the number of guests is limited.

This type of home stay either keeps the original structure of the building or adds "home-like" characteristics by decorating wooden furniture and creating a home-like environment for the guests.

Boutique hotel homestays can accommodate a large number of tourists. The owner of the house operates the business. It offers facilities and cultural management. The guests can learn the local way of life through the activities provided such as preparing lotus decorations for the alms giving ceremony in the morning.

This type of homestay is the renovation of an old building. Home characteristics are still conserved while decorations resembling a thematic hotel are added. For example, there is 
an extension at the rear of the building (keeping the old structure at the front) to support a large number of tourists. There is a seminar room and many of the same facilities as a hotel.

The common objectives of these three categories of homestay are to promote a unique experience of the traditional local way of life in Amphawa and create a cultural exchange between visitors and the owner of the house.

"Tourism development plans should concern activities that clearly present the unique identity of the place and reflect the ability of the community to respond to the needs of the tourists. The main focus of the plans is not only on increasing economic income but also personnel development at all levels, including the owners of the houses, local people in the community, and the tourists." [9]

The characteristics of historical houses modified for tourist accommodation or homestay in Amphawa are shown in Table II.

TABLE II: THE CHARACTERISTICS OF HISTORICAL BUILDINGS MODIFIED FOR HOMESTAYS FROM THE POINT OF VIEW OF THE HOMESTAY OWNER

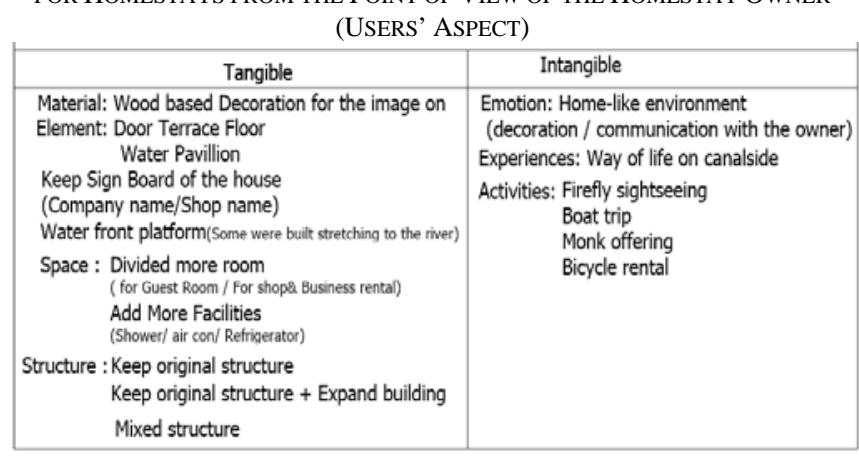

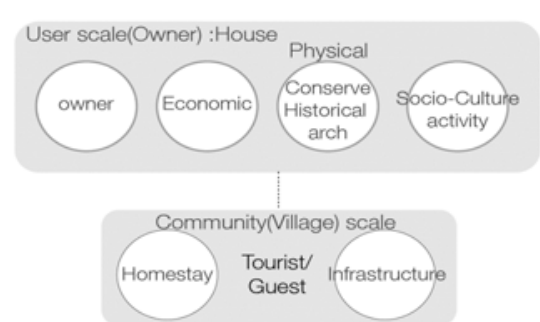

Fig. 8. Key factors that stimulate the modification of historical houses to homestays in the Amphawa Community [7].

Data collected from interviews with the owners (users) show that key factors for the modification of historical houses into homestays in the Amphawa canal community can be divided into two scales (Fig. 8).

1) User scale: the key factors are home stay owner, economics, awareness of the conservation of traditional architecture and socio-culture activity. These are private modifications carried out both unorganized and organized by locals.

2) Community scale: the outcome of the first scale factors resulting in the modification of historical or traditional buildings into homestays along the Amphawa Canal, including the construction of infrastructure in the area.

\section{TOURIST SATISFACTION}

A review of existing definitions in cultural tourism shows

that the term cultural heritage tourism” has been used to describe not only the consumption of art, monuments, folklore, building heritage and cultural manifestations, but also to describe experiences pursued and the motivation of travellers at destinations. As a solution, the Cultural Tourism Research Project by the European Association for Tourism and Leisure Education, Atlas, G. Richard [10] has designed a dual definition of cultural tourism. The first, a conceptual definition, is the movement of persons to cultural attractions away from their normal place of residence, with the intention of gathering new information and experiences to satisfy their cultural needs. This incorporates the attitudinal, experiential and interpretive dimensions of cultural tourism. The second, a technical definition, regards cultural tourism as all movement of persons to specific cultural attractions, such as heritage sites, artistic and cultural manifestations, arts and drama outside their normal place of residence [10].

Tourist satisfaction is a measure of how a service supplied meets or surpasses a guest's expectation. It is seen as a key performance indicator in providing products and services to the community in order to create and control factors appropriate to urban regeneration and modification of historical houses into homestays in Amphawa. However, these concepts are clearly related since we might use customer reaction (satisfaction/dissatisfaction) as a means of evaluating whether the right quality has been delivered.

As well as from the owners' aspect, the tourist's point of view was obtained from visitors or guests who visited various types of homestays in Amphawa. The data was collected by questionnaire to clarify the understanding and point of view of the homestay guests (tourists).

a) Tourist Gender

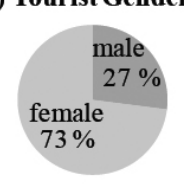

c) Tourist Status
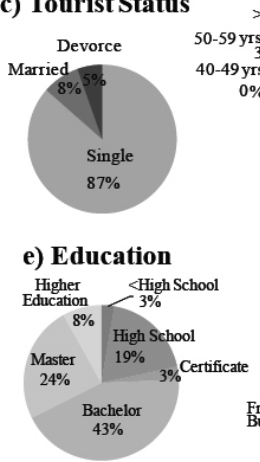

Fig. 9. Demographic of tourists (Homestay guests).

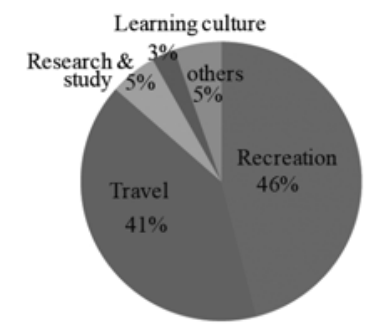

Fig. 10. Objective of stay in Amphawa homestay. 


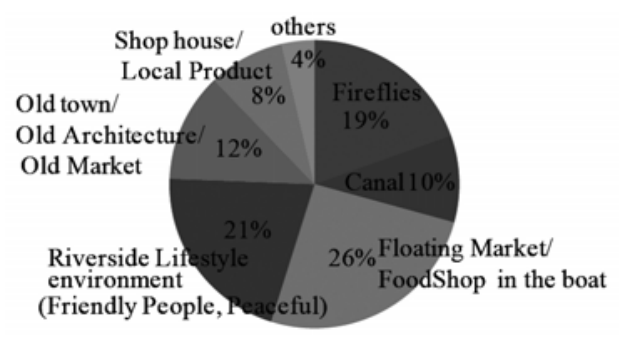

Fig. 11. Identity of the Amphawa community from tourists'/guests' aspect).

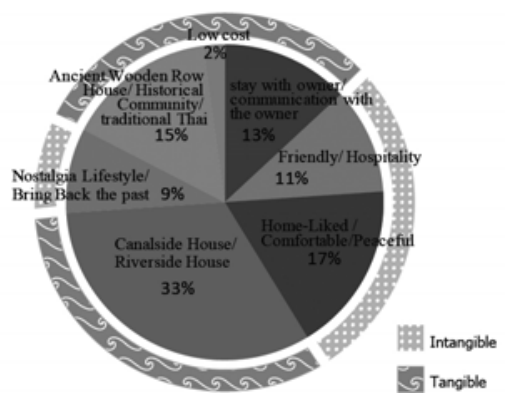

Fig. 12. Identity of the Amphawa homestay from tourists'/guests' aspect.

TABLE III: TOURISTS’ SATISFACTION ON THE AMPHAWA HOMESTAY

\begin{tabular}{|c|c|c|c|c|c|}
\hline \multirow{2}{*}{ Tourists' Satisfactio } & \multicolumn{5}{|c|}{ Satisfaction Level } \\
\hline & 5 & 4 & 3 & 2 & 1 \\
\hline \multirow{2}{*}{ 1)Homestay Publication } & \begin{tabular}{l|l}
6 & 4 \\
\end{tabular} & \begin{tabular}{|l|l}
8 & 6 \\
\end{tabular} & \begin{tabular}{l|l}
6 & 4
\end{tabular} & \begin{tabular}{l|l}
0 & 3 \\
\end{tabular} & \begin{tabular}{l|l}
0 & 0
\end{tabular} \\
\hline & 10 & 14 & 10 & 3 & \\
\hline \multirow{2}{*}{ 2)Convenience to reach } & \begin{tabular}{l|l}
10 & 5
\end{tabular} & & & \begin{tabular}{l|l}
2 & 1
\end{tabular} & \\
\hline & 15 & 16 & 3 & & \\
\hline \multirow{2}{*}{ 3)Convenience on reservation } & \begin{tabular}{|l|l|}
9 & 6 \\
\end{tabular} & \begin{tabular}{|l|l|}
7 & 6 \\
\end{tabular} & \begin{tabular}{l|l}
4 & 5 \\
\end{tabular} & \begin{tabular}{l|l}
0 & 0 \\
\end{tabular} & \\
\hline & 15 & 13 & 9 & 0 & \\
\hline \multirow{2}{*}{ 4)Place's satisfaction } & \begin{tabular}{l|l}
9 & 10 \\
\end{tabular} & \begin{tabular}{l|l}
7 & 7 \\
\end{tabular} & \begin{tabular}{l|l}
2 & 0 \\
\end{tabular} & \begin{tabular}{|l|l}
2 & 0 \\
\end{tabular} & \begin{tabular}{|l|l|l|l}
0 & 0 \\
\end{tabular} \\
\hline & 19 & 14 & 2 & 2 & 0 \\
\hline \multirow{2}{*}{ 5)Community's sastisfaction } & \begin{tabular}{l|l}
8 & 7
\end{tabular} & \begin{tabular}{l|l}
5 & 2
\end{tabular} & \begin{tabular}{l|l}
2 & 2 \\
\end{tabular} & \begin{tabular}{l|l}
0 & 0
\end{tabular} & \begin{tabular}{|l|l|l|l}
0 & 0 \\
\end{tabular} \\
\hline & 15 & 7 & 4 & 0 & \\
\hline \multirow{2}{*}{ 6)Tourist spot of the community } & \begin{tabular}{l|l}
9 & 8 \\
\end{tabular} & \begin{tabular}{l|l}
8 & 8 \\
\end{tabular} & \begin{tabular}{l|l}
3 & 0 \\
\end{tabular} & \begin{tabular}{l|l}
0 & 0 \\
\end{tabular} & \\
\hline & 17 & 16 & 3 & 0 & \\
\hline \multirow{2}{*}{ 7)Nearby tourist spot } & \begin{tabular}{l|l}
8 & 7 \\
\end{tabular} & \begin{tabular}{l|l}
9 & 5 \\
\end{tabular} & \begin{tabular}{l|l}
2 & 2 \\
\end{tabular} & \begin{tabular}{l|l}
1 & 2 \\
\end{tabular} & \begin{tabular}{l|l}
0 & 0 \\
\end{tabular} \\
\hline & 15 & 14 & 4 & 3 & \\
\hline \multirow{2}{*}{ 8)Lifestyle in the comunity } & \begin{tabular}{l|l}
9 & 9 \\
\end{tabular} & \begin{tabular}{|l|l|}
8 & 5 \\
\end{tabular} & \begin{tabular}{l|l}
3 & 3 \\
\end{tabular} & \begin{tabular}{l|l}
0 & 0
\end{tabular} & \begin{tabular}{|l|l|l|l}
0 & 0 \\
\end{tabular} \\
\hline & \begin{tabular}{l|l}
18 \\
10
\end{tabular} & 13 & 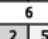 & 0 & 0 \\
\hline 9)Tradition/ Culture of the place & $\frac{10}{10} 5$ & 15 & 215 & \begin{tabular}{l|l}
0 & 0 \\
\end{tabular} & \begin{tabular}{l|l}
0 & 0 \\
\end{tabular} \\
\hline \multirow{2}{*}{ 10)Community welcome } & \begin{tabular}{|l|l|}
12 & 12 \\
\end{tabular} & & & \begin{tabular}{l|l}
0 & 0 \\
\end{tabular} & \begin{tabular}{l|l|l}
0 & 0 \\
\end{tabular} \\
\hline & 24 & 11 & $\frac{1}{2}$ & 0 & \\
\hline \multirow{2}{*}{ 11)Period of Stay } & \begin{tabular}{|l|l|}
8 \\
\end{tabular} & \begin{tabular}{l|l}
9 & 9 \\
\end{tabular} & \begin{tabular}{l|l}
3 & 0 \\
\end{tabular} & \begin{tabular}{l|l}
0 & 0
\end{tabular} & \begin{tabular}{|l|l|l|l} 
& 0
\end{tabular} \\
\hline & 16 & 18 & 3 & 0 & \\
\hline 12)Price of the Homestay & \begin{tabular}{|l|l|}
6 & 8 \\
\end{tabular} & \begin{tabular}{|l|l}
10 & 8 \\
\end{tabular} & & \begin{tabular}{l|l}
2 & 0 \\
\end{tabular} & \begin{tabular}{l|l}
0 & 0
\end{tabular} \\
\hline \multirow{2}{*}{ 13)Willing to return } & \begin{tabular}{|l|l|l|}
12 & 10
\end{tabular} & $4 \mid 6$ & 41 & 20 & \\
\hline & & & & & \\
\hline & & & & & \\
\hline $\exp$ & & & & & \\
\hline
\end{tabular}

These studies, show in Fig. 9-Fig. 12 and Tourists' satisfaction in Table III, emphasized that the identification of tourist " characteristics and an investigation of the relationship between attributes and tourist" satisfaction is needed. It is argued that such research efforts could help tourism practitioners and planners to have a better understanding of cultural heritage tourism and formulate better strategy and planning in cultural heritage tourism.

\section{THE FACTORS THAT CREATE THE IDEA OF MODIFICATION OF HISTORICAL BUILDINGS INTO HOMESTAYS IN THE AMPHAWA COMMUNITY}

Data collection from interview and questionnaire can conclude more key factors for the modification of historical houses into homestays in the Amphawa Canal Community (Fig. 13).

Besides the users scale and community scale previously mentioned, there is a tourist or guest scale. From these studies, it has been discovered that an understanding of the Amphawa image by tourists; river based way of life experience, tradition and culture learning, historical objective, local foods and products and safety and Cleanliness, is needed to keep and complete in sustainable infrastructure on urban regeneration in the future. However conservation scales are needed to control and regulate to sustain and steer the community in the right direction.

In conclusion, from the study of the users' points of view and tourists' aspect on the modification of traditional houses to home stay in Amphawa, sustainable tourism concepts are presented through cultural conservation of traditional building design, cultural activities and traditions, and local way of life along the Amphawa Canal. A sense of home and personal possessions help to create a memorable experience and provide satisfaction in local living among the tourists who come to visit Amphawa. The tangible and intangible identity of the community has become a tourism product of the city.

The study of circumstances related to local tourism development in Amphawa shows that the main obstacle to sustainable development in the country is the lack of proper management. There is a need for clearer management and an ethically responsible framework to create better development of local communities in the future.

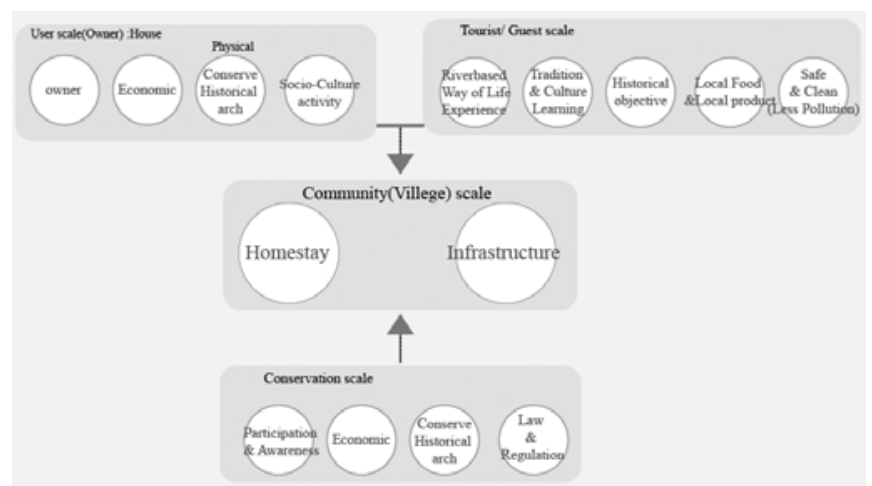

Fig. 13. The key factors for the modification of historical houses into homestays.

From the tourists' aspect, this current study was conducted with these observations in mind. Tourists are satisfied in Amphawa this success needs to result in action. Firstly, more information outlets have to be created in various markets. Secondly, the Thai tourism industry and government should work more closely with the community to spread awareness and remove hurdles. Finally, the local communities have to work towards getting tie-ups with various travel agencies and tour operators to build up awareness of quality among domestic and international tourists. There is no doubt that with good management in urban regeneration, Amphawa homestays have immense potential and will receive more domestic and international tourists in future. It could also become a model for providing cultural and traditional tourism in the world.

In order to create a positive impact and minimize negative effects from sustainable tourism development in the community, ethical, environmental, and social concerns should be added into the plans. Social awareness of the conservation of natural resources and cultural restoration 
should be developed in line with the stimulation of economic income in local communities such as Amphawa.

The operation of homestays in Amphawa has stimulated the use of traditional buildings along the canal. However, a lack of proper budget management, material usage, and mutual understanding of homestay management still obstruct sustainable tourism development in the community.

From the research, cultural conservation is a broader and holistic term which needs wider and comprehensive policies for the protection of collective memories. Although there are some legal and institutional frameworks which need to play an important role in the conservation of a vernacular built environment and cultural values, the community has a key role in achieving sustainable results in urban development. Community involvement provides more diverse policies, open and transparent procedures and a strong sense of belonging and ownership of their ancestors' social, cultural and historical values. In the case of Amphawa, the modification of historical buildings into homestays is a new idea for sustainable urban regeneration, and in order to limit social conflict and stimulate socio cultural exchange within the community, different strategies are required. As mentioned before, the coordination between visitors, tourism professionals, and the host family, pre-travel information, on-site interpretation, social marketing practice and facility design are the key strategies. Community involvement will create a value system for intellectual, spiritual and aesthetic development which summarizes the whole "way of life" of the people along the Amphawa Canal.

For further study, examples of successful cultural tourism management need to be explored. The study of those successful models as examples of good conservation management and maintenance in Japan or nearby countries would be useful for sustainable infrastructure and conservation of Thailand in the future.

The researcher hopes that this paper can provide some ideas to point Thailand in the right direction for future sustainable tourism development with well managed cultural identity to retain its authenticity.

\section{ACKNOWLEDGMENT}

We are grateful to all interviewees, respondents, members of Nakagawa Laboratory, and Ishida Laboratory of the Department of Architecture and Design, Kyoto Institute of Technology for research collection processes during the research. S. Naphasinee thanks all members in family and friends for theirs encourage in this research.

\section{REFERENCES}

[1] L. Duangjai, "State, capital and the community in sustainable tourism management: A comparative study of Thailand and Japan,” Ph.D. dissertation, Thammasart Univ. Bkk, Thailand, 2007, pp. 7-51.

[2] N. Lertwit, "Tourist accommodation development in the Amphawa waterfront neighborhood, Amphawa district, Samut Songkhram Prov ince,” M.S. thesis, Dept. Arch. Arch., Chulalongkorn Univ. Bkk, Thailand, 2009.
[3] P. Niramon, "Architect volunteer from faculty of architecture: Chulalongkron University to Amphawa community. Arch.," Chulalongkorn Univ, pp. 96-113, August 2006.

[4] S. Siriwan, "Experience in cultural environment conservation in Amphawa canal community. Arch.,” Chulalongkorn Univ. pp. 52-67, August 2006.

[5] Office of the National Economic and Social Development Board. The National Economic and social development plan. Bkk. Thailand. pp. 1-7, 55-70. [Online]. Available: http://www.nesdb.go.th/

[6] P. Wannasilpa. "The changes in land and building use in Amphawa Municipality: effects of restoration and development plans in the local community during 2001-2010,” presented at Sufficiency Economic Conf., Chulalongkorn Univ., Bkk, Thailand, December 24, 2010, pp. 15.

[7] S. Naphasinee, Nakhara journal of environmental design and planning, vol. 9, Chulalongkorn Univ. Bkk, Thailand, 2013.

[8] Google Earth. (November 2012). The map of Amphawa Canal. [Online]. Available: http://www.googleearth. com.

[9] C. Gunn. "A perspective on the purpose and nature of tourism research method," in Travel Tourism and Hospitality Research, J. Ritchie and C. Goeldner , Ed. Chichester, Wiley, 1987, pp. 3-12.

[10] G. Richards. Cultural Tourism in Europe. CABI, Wallingford, UK., 1996, pp. 21-39.

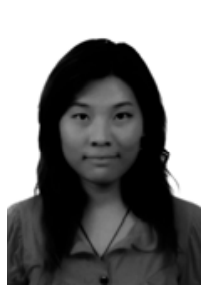

Naphasinee Suebsuk was born in Bangkok, Thailand on January $1^{\text {st }} 1982$. She has graduated with a bachelor degree major in industrial design, at the Faculty of Architecture, Chulalongkorn University, and Bangkok, Thailand in 2004 and continued master degree in 2008-2009 in cultural management, Graduate School, Chulalongkorn University, Bangkok, Thailand. At present, she is a $\mathrm{PhD}$ student in the Nakagawa Laboratory, School of Science and Technology, Department of Architecture and Design, Kyoto Institute of Technology, Kyoto, Japan (since 2012).

Through Chinese language study in Shanghai Normal University, Shanghai China between 2005-2006, she has experience on the research of Chinese water-based town culture which has influenced her research study for a master degree "The interpretation of water based village for sustainable cultural tourism in a case study of Bang Nam Peung District, Samuthprakan Province, Thailand". During the period of study for master degree, she has experience of a Thematic town's interpretation workshop (York-London) for the exchange study programme at York University, York, England in 2008 and was chosen for a fellowship on the research of Thai-Burmar Railway as War Heritage in Kanchanaburi Province, Thailand which is a co-study project through the field study of Australia War Memorial (Canberra-Melbourne) between Chulalongkorn University, Bangkok, Thailand and Deakin University, Melbourne, Australia.

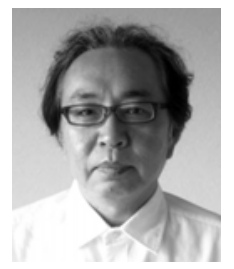

Osamu Nakagawa was born in Yokohama, Japan on July $16^{\text {th }} 1955$. The author graduated with a bachelor degree from the Department of Architecture, Faculty of Engineering, Kyoto University, Kyoto, Japan in 1980, master course of architecture in 1983 and Graduated from a doctoral course in architecture in 1988 from Graduate School of engineering, Kyoto University, Kyoto, Japan. At a present, he is a professor, at the School of Science and Technology, Department of Architecture and Design, Kyoto Institute of Technology, Kyoto, Japan (since 2003).

He once worked as a research fellow of the Japan Society for the Promotion of Science, 1989.4-1991.3 and Associate Professor at the School of Science and Technology, Department of Architecture and Design, Kyoto Institute of Technology, 1992.4-2003.4.

He was rewarded Encouragement Prize of CPIJ (The City Planning Institute of Japan), 1991.5; Encouragement Prize of Architectural Institute of Japan, 1993.5; The Prize of AIJ (Architectural Institute of Japan) for Education, 2013.5.

He also attended Social Activities as Editorial Board Chairman of Journal of the Society of Architectural Historians of Japan; Chairman of the Research Sub-Committee on Urban History of Architectural Institute of Japan. 